\title{
Young Spanish au pairs in London: migration and gender tensions in the context of intra-EU mobilities
}

\author{
Almudena Cortés ， Beatriz Moncó Rebollo , and Fernando Barbosa \\ Social Anthropology and Social Psychology Department, Complutense University of Madrid (UCM), Madrid, Spain
}

\begin{abstract}
This article explores the study of young Spanish au pairs in London within the context of intra-European migration following the 2008 financial crisis from an ethnographic, feminist and gender perspective. It contributes to a greater understanding of the ways in which the free movement of workers in the EU and the commodification of care work are linked to emerging dynamics of European (re)peripheralisation and the production of new forms of precarity. Based on ethnographic fieldwork conducted in 2015 and 2017, it shows how the ambiguous, transient nature of the "au pair" category forces young female migrants to constantly renegotiate gender norms. Their experiences are shaped by gender norms that draw on the sexual division of labour to naturalize caregiving and by gender imaginaries of equal opportunities that challenge the gender order, as gender tensions intersect with the production of new forms of precarity that increase deregulation and heighten vulnerability.
\end{abstract}

ARTICLE HISTORY

Received 12 June 2019

Accepted 19 May 2020

KEYWORDS

Gender, intra-EU mobility, Spanish migration, young migrants, au pairs, domestic work

CONTACT Almudena Cortés almudena.cortes@cps.ucm.es

(C) 2020 Informa UK Limited, trading as Taylor \& Francis Group

\section{Introduction}

This study focuses on the migration of young Spanish au pairs to London in the context of intra-European mobility following the 2008 economic crisis from a gender perspective. Recent emigration from Spain has taken place amid economic recession and increasingly precarious working conditions both of which have resulted in a transformation of the patterns of intra-European migration. Rising unemployment rates, lower job security and poorer living standards, as well as an increased risk of losing personal autonomy, have become widespread in Spain since the economic downturn. Our article is of interest for two main reasons. On the one hand, it contributes to the recent body of research on new intra-European migration flows from Southern European countries (Dominguez-Mujica, Diaz-Hernandez, and Parreño-Castellano 2016; Glorius and Domínguez-Mujica 2017; Lafleur and Stanek 2017) using new reformulations of the coreperiphery approach. Specifically, this article focuses on migration to London by young Spaniards, a phenomenon that has been studied from a variety of different angles (Cortés, Moncó, and Betrisey 2015; Jendrissek 2016; Leon-Himmelstine and King 2020; McCarthy 2019; Nijhoff and Gordano 2017; Pumares 2017) but which requires further attention, especially from a gender perspective.

On the other hand, the article explores the case study of young Spanish women working as au pairs in London, adopting a feminist and gender perspective that has been largely absent from recent analyses of intra-European migration, especially new emigration from Spain (exceptions include Cortés, Moncó, and Barbosa 2019; González Enríquez and Triandafyllidou 2016; Oso 2017). Although the presence of Spanish women in the domestic work sector is not a new phenomenon in the United Kingdom, the topic is of interest due to the fact that au pair work has re-emerged since 2008 as a significant labour niche for young Spanish women migrating to London to escape precarious conditions in Spain. Upon arriving in the city, they join the highly precarious, deregulated domestic work sector with low salaries, poor visibility and low social status. Despite this, Spanish au pair migration has attracted relatively little attention from researchers of intraEuropean migration (exceptions include Muñoz-Rodríguez and Santos 2015, 2018). This article therefore seeks to address this gap in the literature by analysing the case study of Spanish au pairs from an ethnographic, feminist and gender perspective. Our analysis contributes to a greater understanding of the ways in which the free movement of workers in the EU and the commodification of care work are linked to emerging dynamics of European (re)peripheralisation and the production of new forms of precarity. More specifically, we analyse the ways in which the production of precarity intersects with tensions between traditional gender norms and imaginaries of equality (Donato et al. 2006; Lutz 2008; Morokvasic 2007), helping to maintain and reproduce existing gender hierarchies.

The data used derive from fieldwork conducted in London in 2015 and 2017 as part of two broader research projects about gender and intra-European mobility (see funding information) which were a continuation of a previous project (Cortés, Moncó, and Betrisey 2015); however, this article will focus solely on the case of au pairs, who have replaced workers hired to perform domestic work, thus allowing middle-class British families to reduce their costs. The article is divided into four sections. Firstly, we provide a conceptual framework 
followed by a brief description of the context of Spanish migration to the United Kingdom and some methodological information. We then analyse the tensions between gender imperatives and imaginaries in the case of young Spanish migrants in London. Finally, we offer several conclusions that cast light on the interrelations between the core-periphery nature of intra-European migration and the conflicting gender norms governing mobility.

\section{Conceptual framework}

The analytical framework adopted in this article is based firstly on the idea of Europe as a core-periphery structure and the notion of London as a global city that attracts young graduates and workers from all over Europe and around the world. The core-periphery theory establishes the hierarchical, unequal structure of regions and countries. The development of core regions is driven by resource extraction (labour, capital, raw materials and goods), contributing to the underdevelopment of peripheral regions. International migration is the result of the extraction of human capital and labour from the periphery to the core, which reproduces relationships of dependency in peripheral regions (De Haas 2010). Sassen-Koob (1982) refers to this late twentieth-century pattern of migration as the peripheralisation of the core. The European migration cycle that has been present since the second half of the 2000s echoes the core-periphery migration patterns observed fifty years ago, especially in the case of migration from Southern Europe (King 2015), although new trends have also emerged. The peripheralisation of Eastern Europe with strong migration flows to the core following the fall of the Berlin wall; the consolidation of the United Kingdom and the city of London in particular, as centres attracting current intra-European flows; the reactivation of intra-European migration from Southern European countries to other European centres following the 2008 economic crisis, shaping a refashioned European core-periphery structure; and finally, diversity in the composition of flows in the context of mobility regimes are emerging characteristics of the new patterns of core-periphery migration in Europe (King et al. 2016).

With this last point in mind, analysis of intra-European migration must take into account the production of a specific type of social hierarchy based on the juxtaposition of two categories: migration and mobility. While the former refers to labour migration, which may be regular or irregular, the latter makes reference to so-called highly skilled migrants. Labour migrants are known as immigrants, whereas highly skilled migrants are often not (Faist 2013), but all engage in mobility. This distinction is key, as contemporary mobility forms the backdrop against which notions of employability and of the investment that individuals are required to make in their human capital are reconfigured (Muñoz-Rodríguez and Santos 2015). Narratives around internationalization and mobility have taken hold, framing them as compulsory requirements for enhancing young people's competitiveness. In the case of young, working class people without resources, au pair migration represents a low-cost strategy for investing in their human capital at the cost of increasing their exposure to exploitation in the workplace. The case of Spanish au pairs in London is particularly interesting due to the ambiguity of their status, straddling the categories of migration and mobility. Au pairs are often young foreign women with a university education who are considered "help" rather than labour and are rarely viewed as migrants. However, the nature of their work also excludes them from being considered as skilled workers despite the fact that they are usually university graduates. As shown in this article, au pairs are not covered by labour market regulations and are rendered invisible by the cultural codification of the household chores they perform.

Secondly, our analysis draws on current debates surrounding social reproduction in relation to migration, care practices and gender. Over the last 20 years, the domestic work sector in Europe has been characterized by growth, feminization, concentration of migrants and persistently poor working conditions (Andall 2013; Giordano 2019). Indeed, care-related employment is growing rapidly in many economies and increasing numbers of families (especially middle-class households) and individuals find themselves negotiating commoditised forms of care for themselves, their children, elderly relatives and vulnerable adults (Cox 2013; Ehrenreich and Hochschild 2003; Lutz 2011). It is important to note that growth in the care sector is linked not only to rising instability in the labour market and cuts to social policies but also to the naturalization of care and a persistent failure to question the sexual division of labour within couples. In addition, contemporary domestic work is predominantly carried out by migrant women and disadvantaged groups (ILO 2013). Although paid domestic work was largely performed by women from rural areas (internal migration) in the past, the link between international migration and domestic work has intensified to such an extent that there has been an increased demand for female labour from the South in the North and a global transfer of care, housework and sexual activities (Ehrenreich and Hochschild 2003; Herrera 2012; Parreñas 2001; Piper 2009). In the case of au pairs in the EU, the free movement of European workers has encouraged new forms of peripheralisation based on the extraction of care work from women from Eastern and Southern Europe. It is no coincidence that recruitment programmes for low-skilled workers such as the au pair programme are more widely used by female migrants than men, resulting in greater political exclusion among women (Hennebry, Holliday, and Moniruzzaman 2017), not only among low-skilled migrants but also among middle-class and highly skilled professional migrants (Merla and Baldassar 2016).

The act of migrating can challenge established gender norms and power relations, as well as giving rise to new dependencies and reinforcing existing gender differences and social hierarchies (Morokvasic 2007). The specific case study of Spanish au pairs in London demonstrates that the process of commodification of care work and the production of new forms of precarity in the context of European mobility result in the renegotiation of gender norms by au pairs on an ongoing basis. Au pairs are forced to constantly negotiate between maintaining the traditional gender norms that allow them to work as au pairs and challenging these norms by positioning themselves as workers and citizens with the right to construct autonomous personal and professional lives in London. These dynamics will be analysed in greater depth in this article. 


\section{A brief description of the research context}

Migration flows between Spain and the United Kingdom form part of the historic relationship between the two countries and have been marked by a succession of different phases, including the Spanish exile following the civil war and economic migration from the country in the 1960s and 1970s. At the end of the 1950s, Spanish women began to migrate to the United Kingdom to engage in domestic work, with numbers rising from 1,500 in 1957 to 20,000 in 1968 (Monferrer 2007). Flows of female Spanish migrants were more numerous than male migrants and the work carried out by women was mostly domestic work in houses and hospitals or work for the hotel and catering industry (Bravo Moreno 1999). Spanish and Portuguese women were present in London households as domestic workers and cleaners alongside British women, who continued to work in the sector until the 1980s.

As London was gradually transformed into a global city, a leader in the international economy and a hub of cultural life, it also became one of the Spanish population's preferred destinations for work, study or spending time in a more democratically open society. Interestingly, it is estimated that from 1974 to 1988 almost 200,000 Spanish women travelled to the UK to obtain an abortion at a time when it was impossible to do so in Spain (Peiró et al. 1994). When Spain joined the EU, the option of working as an au pair in the United Kingdom and combining (or at least attempting to combine) work and study came to form part of many young Spanish women's imaginaries. From the 2008 economic crisis, this migration flow towards the United Kingdom was reactivated in the context of new Spanish migration to Europe.

Data from the Spanish National Institute of Statistics (INE - Residential Variation Statistics) show that since 2008 the UK has been the most popular destination for Spanish migrants. France and Germany are the second and fourth preferred destinations in the EU respectively, while the third is the USA. According to these data, from 2008 to 2018, 117,968 Spaniards emigrated to the United Kingdom, with the greatest concentration occurring in 2014 and 2016, when 15,094 and 15,605 people left Spain for the UK respectively. From 2016, arrivals of Spanish migrants began to fall in number, reaching 13,667 in 2018 (latest available date). It is relevant to note that more women than men migrated during the $2008-18$ period.

Meanwhile, data from the Office for National Statistics (ONS 2017) on Spanish residents in the UK by sex for the 2007-17 period show as well that there is a predominance of women over men, especially since 2011, coinciding with the worst years of the economic crisis in Spain. National Insurance Number (NIN) applications in the UK are another source of relevant information on the composition of migrant populations. Here, the Spanish population is ranked fourth behind Romanian, Polish and Italian nationals. The data refer to applications from people working in the formal sector and do not include jobs in deregulated sectors which do not require a NIN, as is the case of au pairs, so the total number of Spanish workers may be higher than the number of NIN applications. During the 2014-17 period, a slight downward trend can be observed in NIN applications from Romanian, Polish and Spanish nationals. This reflects the general decline in the EU population resident in the UK following the Brexit referendum which culminated in the UK leaving the EU.

Finally, according to data from the UK Department for Work and Pensions, the Spanish population in the United Kingdom resides primarily in England and is concentrated in certain well-connected, central areas of Greater London, such as Southwark or Tower Hamlets, or in areas further away from the centre, such as Waltham Forest or Hammersmith and Fulham, where housing is more affordable. Other cities with large numbers of Spanish migrants are, in descending order, Manchester, Bristol and Brighton.

\section{Methodology}

The data used in this article derive from ethnographic fieldwork conducted in London in 2015 and 2017 as part of two research projects about gender and intra-European mobility (see endnote 1). Forty-two in-depth interviews with migrants of Spanish nationality were conducted in the Greater London area. The sample took into account sex; skill level of work performed in London, with occupations including telecommunications engineering, research, entertainment, financial services, au pair work, cleaning, dishwashing, fast food, construction and unemployment; age (18-30 years); and length of residence (from 5 to 15 years).

This article will focus solely on au pairs. The au pairs in our study were mostly young women with secondary and/or higher education, who were working or had worked as au pairs in the expectation that this would help them to find better work and improve their English level. Sixteen in-depth interviews were conducted with fifteen women and one man, who were working or had worked as au pairs at the time of the interview. All the au pairs interviewed had been unemployed in Spain or working in jobs with precarious conditions that often did not match their skill level. They were all born in Spain and were aged between 18 and 26. With regard to their level of education, seven of the interviewees had graduated from university, while eight had completed secondary school and one had attended vocational training. Among the sixteen, ten had found employment in other sectors following a period of work as au pairs, working as assistants in clothes shops or fast food outlets, waitresses or home healthcare workers. The interviews focused on exploring the participants' family backgrounds and migration, educational and professional trajectories in Spain and London, as well as their experiences of the economic crisis, care work and Brexit, with the aim of performing a gender analysis. Interviewees were selected through various channels: personal contacts, organized groups and social networks. Most of the people interviewed did not know one another.

\section{Au pairs in the UK: a threefold invisibility}

The Brexit referendum helped to reveal the degree to which the United Kingdom depends on poorly paid, highly flexible labour from the EU (Cox 2018). According to Cox $(2018,1)$, "100,000 families in the UK depend on EU workers for care work, one sector that may be particularly affected by the loss of EU workers". During the last decade in particular, British households have taken advantage of the free 
movement of EU citizens to meet their childcare needs by hiring au pairs, who remain largely invisible and are able to adapt to the demands of the labour market and the model of care.

$\mathrm{Au}$ pair work is subject to a threefold invisibility. Firstly, care work is carried out in the family environment for free as an altruistic activity which is not viewed as "real" work. Secondly, it is bound up with affection and moral obligation, making it very difficult to recognize that the people performing this work possess labour rights, especially if the relationship is viewed as a cultural exchange (Búriková 2015). The figure of the au pair constitutes a special category which is neither student nor worker, occupying both categories simultaneously. It is not a job per se as au pairs pay neither taxes nor Social Security contributions. Finally, this work is mostly carried out by women, as part of their natural role under the cultural assumptions that naturalize this work (Comas 2017; Cox 2018). Due to the invisible nature of au pair work, the sector is not regulated and there is no official definition of "au pair". However, in the United Kingdom, an au pair is informally understood to be a young woman, most often from another EU country, who works between 25 and 30 hours a week looking after children and carrying out domestic tasks in exchange for accommodation, meals and pocket money, and who is treated as "a member of the family". From 2008, the British government encouraged the arrival of au pairs to shore up the care sector after the au pair visa was abolished (Cox 2013).

The figure of the au pair was initially associated with an exchange between young, single women from "good families" in the middle and upper classes of England, France and Germany in the 1920s (Cuartas 2014). This activity supplemented the work performed by nannies and domestic workers, and was a form of social distinction (Cox 2018). However, as the care sector has become more precarious, nannies and domestic workers have been replaced by au pairs, who work in unstable, unregulated, flexible conditions for low pay.

\section{Spanish au pairs and tensions within the gender order}

The act of migrating can lead to increased autonomy and challenges to established gender norms but it can also cause the gender order to be reproduced (Morokvasic 2013). The case study of Spanish au pairs in London is a perfect illustration of the fluid, ambiguous position that au pairs must adopt with regard to gender norms. One of the key elements of this kind of work is that au pairs must adapt seamlessly to hegemonic gender representations regarding the role of women in the home. This was the case of Susana, an au pair who had graduated in Spanish Literature in Spain and, in response to a lack of job opportunities, moved to London in order to gain work experience in a safe, family environment:

There was a married couple my parents' friends knew of who lived in Washington, and I contacted her to help me find a family. I met the girl, who was also Catalan, they are a whole Spanish family, I liked her, and I decided to come. And for me it is my second family, from the beginning I have been with a mentality that I would move here with my "parents" and I was the older sister and would have to lend a hand at home. (Susana, 25 years old, au pair, London, 2017)

Susana took advantage of family contacts to move to London and reduce the personal and economic costs of her migration. For her, rather than a job, being in London is an opportunity to learn English in a family environment where she takes on the role of an "elder sister" in the family rather than that of a worker. Being part of the family also means sharing domestic obligations, so Susana has an implicit duty to lend a hand around the house. Echoing this same dynamic, Beatriz's experience illustrates the way in which gender imperatives are internalized by au pairs themselves. Beatriz had spent time in Sweden as an Erasmus student as part of her degree in Political Science and International Cooperation. During her time abroad, she was affected by cuts to the education system in Spain, but her family were unable to help her as they were experiencing a difficult financial situation themselves. When she graduated from university, she decided to move to London in order to further improve her English due to the lack of opportunities in Spain. The first job she found was as an au pair. Despite the father of her host family only asking her to take care of his young child and talk to him in Spanish, for her it was implicit that she would also have to perform household chores:

I was very lucky; in my case it was a half-hippy father, so I didn't have to do anything at all in the house. I would do the breakfast dishes, go to pick up the boy at 3 o'clock and stay with the infant from 3 to $6: 15 \mathrm{pm}$ and the father just wanted me to be with the child, not cleaning up anything at home. The father told me: "You play with him, do your homework with him, everything with him, forget about the house" ... and what I had to do was wash the dinner plates and he cooked and if I wanted to cook that day he would wash the dishes. I cleaned the house because although he didn't ask me to do the dishes or clean the house, I did it to balance the relationship, even to avoid comments from the mother ... (Beatriz, 31 years old, au pair, London, 2015)

Beatriz and Susana exemplify what is referred to as the "moral economy' of domestic work", that is, the reward for the work carried out is affective rather than monetary within a mutual moral contract characterized by inequality and gendered relations within the family (Hess and Puckhaber 2004, 69). Au pairs can therefore be part of the family without truly belonging and work without being viewed as employees, neutralizing any labour demands or conflicts arising in what is a family context rather than a professional one. Moreover, as part of their family and affective obligations, the parents in the host families may ask au pairs for changes to their working hours and tasks, just as they would do with elder siblings in the family.

Another dynamic which is central to au pair work is the intensification of sexual difference. Supply and demand for labour in household services is highly gendered. While men may work in certain occupations such as gardening and window cleaning, most are female 
dominated (Anderson 2007). Thus, the figure of the au pair is based on and reproduces sexual difference. While au pair positions are mostly occupied by young women (up to 27 years old), men have also been present in the sector since 1993, albeit in very small numbers. However, recruiters remain more inclined to hire women as au pairs. They are reluctant to employ men, as many parents continue to consider it inappropriate for men to care for young children and worry about leaving pubescent girls in the care of a man (Anderson 2007). One of our interviewees, Fernando, 25 years old, had been living in London for more than a year. He obtained a higher vocational diploma in Leisure and Recreation in Spain before becoming unemployed. After ending a relationship and realizing he could not afford to pay for English classes to improve his low English level, he decided to move to London to work as an au pair. However, he found it harder to find work than he had thought:

I talked to families on Skype and they told me I was very nice, and my English was not as bad as I said, but that they were looking for a woman ... as a guy I was more limited. I mean, a girl here can say that she wants to be an au pair in London in such and such a neighbourhood and she'll have offers from 4 or 5 families. If I choose only London it is very likely that nobody will answer. It is sad but true. Families just think that being a woman, you will have a better feel for children, you will know how to take care of a house and so on, which is awful, but that's how it is. I know how to handle kids, I know how to cook, I'm pretty good at cooking, and everyone knows how to do housework. (Fernando, 25 years old, au pair, London, 2017)

Fernando's complaint at how "awful" it is for care to be naturally attributed to women demonstrates the persistence of a gender order and sexual division of labour in which women are associated with reproductive work. In reality, Fernando is calling for a denaturalization of caregiving, a long-standing demand of the feminist agenda, which would allow him to enter a niche that is currently off-limits to him and expand his options on the labour market. Although these distinctions may appear obsolete, gender analysis allows us to demonstrate their continued influence on the social order. The hiring of au pairs is informed by a sexed discourse which privileges the feminine over the masculine, identifying the feminine with motherhood and care. Male caretakers of children often provoke distrust: it is not their "natural" role and represents a betrayal of the values of hegemonic masculinity. Moreover, the female au pairs interviewed explained that their male counterparts experienced less restrictive control over their use of time and space than they did. To return to our example, the parents in Fernando's host family had asked him only to take care of the children, making it clear that he was not required to clean the house. However, some of the female au pairs interviewed are also expected to carry out domestic tasks, assuming a natural secondment to these types of duties.

Another key element is that the gender order is imposed on women's migratory projects through ideas of maternity, reproducing a patriarchal norm based on the new neoliberal "good mother" model. This model of female identity is based on an instinctive interpretation of childrearing, viewing it as the responsibility of women in a clear relegation of women to the home (Alzard 2018). Despite this, the model is framed as a matter of free choice within a discourse of empowerment. In the Spanish case, there are clear echoes of the early Francoist maternal model in the new neoliberal discourse of the "good mother" which is widespread in Europe, including the UK.

The young Spanish female au pairs interviewed form part of a pool of "home help" for middle-class families in London. The impossibility of fulfilling a good mother model based on attachment and home care as a natural attribute of women and the mother/child relationship generates a series of anxieties for mothers who cannot perform these tasks. Mothers compensate for their absence in the home by hiring an au pair with higher education at low cost (considered a better option than sending children to day care) (Cox 2013) thanks to the core-periphery relationship established between London as a global city and other peripheral regions of Europe. The increasingly precarious working conditions of au pairs allow class relationships to be upheld in private homes that employ migrant women as childcare providers (Cox 2013).

The good mother model operates in both directions: it influences both the au pair-family relationship and the au pair-working relationship. Regarding the former, most of the women interviewed in our research are not mothers but many admitted considering having children at some point, especially the younger women, as in the case of Susana, mentioned above:

The truth is that I did not think much, I love being with children and I saw that it was the fastest and easiest option to come ... in addition their ages were OK, 11 months and 3 years old... And then these two years that I did not count as an experience have helped me to learn how to care for children in case I have children in the future. Although I envisage having children one day and, if possible, a large family of 6 or 8 children and take care of them all myself for as long as I can ... this is something that has changed since I've became an au pair, I've always said that I would have children and when I finished maternity leave, I would send them to day care, but now I've changed my mind, I want to be at home. (Susana, London, 2017)

As Susana notes, working as an au pair has allowed her to acquire the necessary skills to run a home and care for her own family in the future, convincing her that her place is in the home. Although she planned to return to work after taking maternity leave before becoming an au pair, she is now convinced that she wants to bring up her children at home.

The strength of this gender imperative weighs on au pairs not only as mothers, but also as good daughters. Most of the au pairs interviewed mention the fact that their parents and families are in Spain and will need care sooner or later, with the expectation that they will be the ones to look after them (prompting a return to Spain): 
My parents are alone ... that's why I also think about going back, because before long they're going to need care. Both are quite old for my age now. Then I know that one day I will have to return, and I will not leave them in a retirement home. I want to take care of them, I want them to live with me. (Yolanda, 29 years old, nursery assistant, London, 2017)

Yolanda arrived in London five years ago and began to work as an au pair. She had completed a degree in Marketing but was unable to find decent work in her field during the financial crisis in Spain and decided to travel to London to try her luck there. The easiest option was to find work as an au pair with a family, where she stayed for two years before finding a job at a nursery school. Yolanda lives in London with her Spanish boyfriend, who works in financial services, and is certain that she wants to have children and return to Spain in the future so that she can take care of her parents. Caring for parents or dependants is normatively associated with women, with a dual impact on their mobility: it can be both an obstacle to migration and one of the reasons for returning and maintaining gender norms and kinship (Cortés and Oso 2017). The gender imperative is activated once again when these women think about a potential future return to Spain to fulfil their role as good daughters who take care of their relatives.

However, at the other extreme, we also find examples of women who challenge the duty to provide care imposed on migrant women under the "good daughter" model. In this sense, Paula's case is especially enlightening. She is 26 years old, works as an au pair and had been living in London for three months in 2017. Her father is a lorry driver and her mother an unemployed hairdresser at the time of the interview. In Spain, Paula completed a vocational training course but had been unemployed for five years. She left her village for Madrid where she worked as a shop assistant, but her salary barely covered the rent for her flat. In response to this situation, she travelled to London where the first job she found was as an au pair. When her mother became ill in Spain, her father and grandmother began to pressure her into returning to take care of her sick mother. However, she decided that her mother was well looked after by her relatives. The gender imperative situates Paula's place in Spain, as a good, only daughter, seeking to impose immobility upon her in the form of care responsibilities, but she opposes this role via a gender imaginary based on her autonomy and fair redistribution of care work, freeing her from the obligations associated with a moral image of what it means to be a "good" daughter.

Thus, the commodification of care is linked to gender norms, promoting inequality in situations of economic crisis (such as in Spain) and exacerbating the feminization of poverty. This is particularly apparent among working class women with few resources who work in the au pair sector, such as Paula or Xandra, a young au pair who had arrived in London a year earlier. Xandra had been studying a professional training course in administration, but left for London before finishing her studies with her boyfriend, who had found work in the construction sector. In light of the lack of job prospects in Spain, she viewed London as an excellent option which offered the most employment opportunities at the time of the interview. She had been forced to change host families three times since arriving in the city due to the poor working conditions imposed upon her. In the case of the first family, she explains:

There were three children aged two, four and ten and, obviously, I always had to be with the infant; I worked fourteen hours a day for ninety pounds a week. [...] We never discussed so many hours [...]. The room did not comply with what I was told, it had a single bed, a baby closet and a window. I couldn't even close the door. And they did not understand that the weekends were free, they got angry if I left, and that's not what being an au pair is [...] I cleaned the house every day thoroughly, did her errands, I did everything for them. At night I felt dead-tired, I caught a throat infection, had a forty-degree fever and they made me work anyway ... At Christmas I took a round trip [to Spain and back] and left them. (Xandra, 26 years old, au pair, London, 2017)

The commoditisation of care has increased precariousness in the sector and is framed within a hierarchy of class, nationality and gender orders, characterized by informal employment structures, low status jobs, labour exploitation and the risk of abuse and sexual assault. The absence of institutional regulation and work contracts, as well as the dynamics of the moral economy, heighten au pairs' vulnerability. In the context of recent intra-European mobility during the economic crisis, the figure of the au pair has become still more ambiguous, leading to the emergence of new forms of social and gender inequality.

\section{Conclusions}

The recent migration of young Spaniards to London to work as au pairs forms part of the new flow of Spanish migrants which was reactivated following the 2008 economic crisis. Unlike Spanish migration in previous decades, this new flow is made up of women with higher education levels who migrate to London as a way of escaping precariousness in Spain, where the labour market is characterized by poor quality work, temporary contracts and job insecurity. However, the trend towards reperipheralisation in which Spanish migration is situated is the result of increasing instability in the domestic work sector in the United Kingdom, poor working conditions and deregulation. Despite the difficult working conditions, expectations of improved access to the labour market in London or Spain in the short-term future and the desire to acquire international experience make au pair work ideal for new arrivals seeking work in London. Although starting out as an au pair can be detrimental to migrants, it can also offer them certain, albeit limited benefits.

The figure of the au pair is interesting as it is an ad hoc, liminal, ambiguous, transient construction, configured in such a way as to be "between" categories, spaces and bounds, responding to families' needs, labour market provision and a lack of regulation and resources from the state. It is this ambiguous, transient status that obliges au pairs to constantly renegotiate gender norms as migrants. The naturalization of caregiving and its attribution to women, as well as the enduring identification of women with the "good mother" model, reinforce gender hierarchies. Yet within this model, we also see strategies of resistance emerge in an attempt to subvert the gender order. Young au pairs take 
advantage of this model as a low-cost strategy for migrating to London in order to boost their competitiveness in the labour market. However, the crisis in the care sector in the UK may be giving rise to new forms of precarity, such as the failure to recognize rights, the deregulation of new labour niches, growing insecurity and vulnerability, etc. This article has demonstrated that the life experience gained by au pairs is a euphemism which conceals a worrying vulnerability for workers, especially young women, within a global political economy of care reliant upon a constant supply of European migrant women in a context of historical and peripheral flows of domestic workers.

\section{Acknowledgements}

The authors thank the guest editors as well as the anonymous evaluators of this article, for their comments that helped to improve the paper.

\section{Funding}

This work was supported by the following research projects: Oso (dir.) (2015-19): "Género, movilidades cruzadas y dinámicas transnacionales", Ministerio de Economia y Competitividad [grant number: FEM2015-67164-R]; Cortés, A. (dir.) "Jóvenes españoles en Londres: Relaciones de género y estrategias transnacionales de movilidad", Ayudas a la investigacion 2016, Centro Reina Sofia de Adolescencia y Juventud.

\section{References}

Alzard, D. 2018. "Del modelo maternal del primer franquismo, al discurso neoliberal de la 'buena madre': mater amantísima, llena de gracia y de símbolos". PhD diss., Universidad Complutense de Madrid.

Andall, J. 2013. "Gendered Mobilities and Work in Europe: An Introduction." Journal of Ethnic and Migration Studies 39 (4): 525-534. Crossref.

Anderson, B. 2007. “A Very Private Business.” European Journal of Women's Studies 14 (3): 247-264. Crossref.

Bravo Moreno, A. 1999. "Gender, Migration and Identity. Spanish Migrant Women in London”. PhD diss., University of London.

Búriková, Z. 2015. “'Good Families' and the Shadows of Servitude: Au Pair Gossip and Norms of Au Pair Employment.” In Au Pairs Lives in Global Context. Sisters or Servants? , edited by Rosie Cox , 36-52. London : Palgrave McMillan.

Comas, D. 2017. “Cuidados, Género y Ciudad en la Gestión de la Vida Cotidiana.” In La Erosión del Espacio Público en la Ciudad Neoliberal , edited by Patricia Ramírez Kuri , 59-91. Mexico City : Instituto de Investigaciones Sociales, UNAM.

Cortés, A. , B. Moncó , and F. Barbosa . 2019. Brexit, Relaciones de Género y Estrategias Intergeneracionales de Movilidad Social: Jóvenes Españoles en Londres . Madrid : Centro Reina Sofía sobre Adolescencia y Juventud.

Cortés, A. , and L. Oso . 2017. "Avecillas y Pájaros en Vuelo Transnacional: Retorno, Género y Estrategias de Movilidad e Inmovilidad Entre Ecuador y España.” Revista Española de Sociología 26 (3): 359-372. Crossref.

Cortés, A. , B. Moncó , and D. Betrisey . 2015. Movilidad Transnacional de Jóvenes Españoles y Latinoamericanos: una Comparación en Contextos de Crisis . Madrid : Centro Reina Sofía sobre Adolescencia y Juventud.

Cox, R. 2013. "Gendered Spaces of Commoditised Care.” Social \& Cultural Geography 14 (5): 491-499. Crossref.

Cox, R. 2018. "Gender, Work, Non-Work and the Invisible Migrant: Au Pairs in Contemporary Britain.” Palgrave Communications 4: 121. Crossref.

Cuartas, L. 2014. “Jóvenes ‘Au Pairs’: Figura Invisible de la Migración y el Empleo Doméstico Internacional.” In Trabajadoras en la Sombra: Dimensiones del Servicio Doméstico Latinoamericano, edited by Séverine Durin, María Eugenia de la O. Martínez, and Santiago Bastos , 563-588. Ciudad de México : Ediciones de la Casa Chata.

De Haas, H. 2010. "Migration and Development: A Theoretical Perspective.” International Migration Review 44 (1): 227-264. Crossref.

Dominguez-Mujica, J. , R. Diaz-Hernandez, and J. M. Parreño-Castellano . 2016. "Migrating Abroad to Get Ahead: The Emigration of Young Spanish Adults During the Financial Crisis (2008-2013).” In Global Change and Human Mobility, edited by Josefina Dominguez-Mujica , 203-223. Singapore : Springer.

Donato, K. , D. Gabaccia , J. Holdaway , M. Manalansan IV , and P. R. Pessar . 2006. "A Glass Half Full? Gender in Migration Studies", International Migration Review , 40 (1), 3-26. Crossref.

Ehrenreich, B. , and A. Hochschild . 2003. Global Woman: Nannies, Maids and Sex Workers in the New Economy. New York : Henry Holt and Company.

Faist, T. 2013. "The Mobility Turn: A New Paradigm for the Social Sciences?” Ethnic and Racial Studies 36 (11): 1637-1646. Crossref.

Giordano, Ch. 2019. "The Role of Gender Regimes in Defining the Dimension, the Functioning and the Workforce Composition of Paid Domestic Work." Feminist Review 122: 95-117. Crossref.

Glorius, B. , and J. Domínguez-Mujica . 2017. European Mobility in Times of Crisis: The New Context of European South-North Migration . Bielefeld : Transcript Verlag.

González Enríquez, C. , and A. Triandafyllidou . 2016. "Female High-Skilled Emigration From Southern Europe and Ireland After the Crisis." In High-Skill Migration and Recession. Migration, Diasporas and Citizenship, edited by Anna Triandafyllidou and Irina Isaakyan, 44-68. London : Palgrave Macmillan.

Hennebry, J. , J. Holliday, and M. Moniruzzaman . 2017. At What Cost? Women Migrant Workers, Remittances and Development . New York : UN Women.

Herrera, G. 2012. "Género y Migración Internacional en la Experiencia Latinoamericana. De la Visibilización del Campo a una Presencia Selectiva." Política y Sociedad 49 (1): 35-46. Crossref.

Hess, S. , and A. Puckhaber . 2004. “'Big Sisters’ Are Better Domestic Servants?! Comments on the Booming au Pair Business.” Feminist Review 77 (1): 65-78. Crossref.

International Labour Organization (ILO) . 2013. Domestic Workers Across the World: Global and Regional Statistics and the Extent of Legal Protection Geneva : International Labour Organisation.

Jendrissek, D. 2016. "Building a Future in Times of Crisis: Young, Highly Qualified Migrants in the UK." Journal of Contemporary European Studies 24 (4): 323-340. Crossref.

King, R. 2015. "Migration and Southern Europe: A Center-Periphery Dynamic?” In Southern Europe? Italy, Spain, Portugal, and Greece From the 1950s Until the Present Day, edited by Martin Baumeister and Roberto Sala, 139-169. Frankfurt : Campus Verlag.

King, R. , A. Lulle , F. Conti , and D. Mueller . 2016. "Eurocity London: A Qualitative Comparison of Graduate Migration From Germany, Italy and Latvia." Comparative Migration Studies 4 (3).

Lafleur, J. M. , and M. Stanek . 2017. South-North Migration of EU Citizens in Times of Crisis . New York: Springer.

Leon-Himmelstine, C. , and R. King . 2020. "Healing Young Hearts: Emotional and Psycho-Social Dimensions of Wellbeing Amongst Young-Adult Spanish Migrants in the London Region." Nordic Journal of Migration Research 9 (2): 161-117. Crossref.

Lutz, H. 2008. Migration and Domestic Work: A European Perspective on a Global Theme. Aldershot : Ashgate.

Lutz, H. 2011. The New Maids: Transnational Women and the Care Economy . London : Zed Books.

McCarthy, H. 2019. "Spanish Nationals' Future Plans in the Context of Brexit.” Population, Space and Place 25: e2202. Crossref. 
Merla, L. , and L. Baldassar . 2016. “Concluding Reflections: 'Care Circulation' in an Increasingly Mobile World: Further Thoughts.” Papers. Revista de Sociología 101 (2): 275-284. Crossref.

Monferrer, L. 2007. Odisea en Albión. Los Republicanos Españoles Exiliados en Gran Bretaña (1936-1977). Madrid : Ediciones de la Torre.

Morokvasic, M. 2013. "Transnational Mobilities and Gender in Europe.” Ars \& Humanitas 7 (2): 45-59. Crossref.

Morokvasic, M. 2007. "Migración, Género y Empoderamiento." In Puntos de Vista, Cuadernos del Observatorio de las Migraciones y de Convivencia Intercultural de la Ciudad de Madrid 9 (3) March.

Muñoz-Rodríguez, D. , and A. Santos . 2015. "Las nuevas precariedades a través de las au pairs universitarias: del cosmopolitismo a los cuidados a bajo coste". Prisma Social - N 15, dic 2015-May 2016, 526-561.

Muñoz-Rodríguez, D. , and A. Santos . 2018. "Una más de la familia. Au pairs atrapadas entre capital humano y la economía moral”. Arxius de sociología, $\mathrm{n}^{\circ} 39$.

Nijhoff, K. , and M. C. Gordano . 2017. "Looking at Intra-European Mobilities Through Migrant Types: Young Spanish and Polish Migrants in London and The Hague." Innovation: The European Journal of Social Science Research 30 (2): 182-203. Crossref.

Office for National Statistics . 2017. Living Abroad: Migration Between Britain and Spain .

Oso, L. 2017. “¿Nuevas Criadas y Porteras en París?: Reactivación de los Campos Sociales Transnacionales de la Emigración Española Tras la Crisis Económica." Migraciones. Publicación del Instituto Universitario de Estudios sobre Migraciones 43 (diciembre): 39-63. Crossref

Parreñas, R. S. 2001. Servants of Globalization: Women, Migration and Domestic Work. Stanford : Stanford University Press.

Peiró, R. , C. Colomer , J. Ashton , and C. Álvarez-Dardet . 1994. “Abortos Inducidos en Mujeres Españolas en Inglaterra y Gales (1974-1988).” Gaceta Sanitaria 8 (8): 57-62. marzo-abril. Crossref

Piper, N. 2009. "The Gendered Political Economy of Migration”, IMDS Working Paper Series, Working Paper no. 17, November 2009, New Delhi: International Migration and Diaspora Studies Project/Jawaharlal Nehru University.

Pumares, P. 2017. "The Changing Migration Projects of Spaniards in the UK. The Case of Brighton." In European Mobility in Times of Crisis: The New Context of European South-North Migration, edited by Birgit Glorius, Domínguez Mujica, and Josefina, 133-160. Bielefeld : Transcript Verlag.

Sassen-Koob, S. 1982. "Recomposition and Peripheralization at the Core." Contemporary Marxism 5: 88-100. 